\title{
High-efficiency gene targeting in a human pre-B cell line: towards the human gene knockout project
}

Noritaka Adachi

From Beyond the Genome: The true gene count, human evolution and disease genomics Boston, MA, USA. 11-13 October 2010

Despite recent rapid progress in gene knockdown technologies, gene knockout studies using human somatic cells will be important for analyzing the functions of human genes in greater detail. Although the frequency of gene targeting is low in human cultured cells, we have recently shown that a human precursor B-cell line, Nalm-6, allows for high-efficiency gene targeting by homologous recombination. The Nalm- 6 cell line was established from the peripheral blood of a 19-year-old man with acute lymphoblastic leukemia, displays a stable diploid karyotype with a single reciprocal translocation, has a doubling-time of $20 \mathrm{hr}$ and a high plating efficiency of $\sim 80 \%$, and expresses normal p53 with wildtype functions. These properties underscore the usefulness of Nalm-6 in gene-knockout studies of human genes.

The gene-targeting efficiency in Nalm-6 cells is typically $\sim 1-5 \%$ when conventional (non-viral) replacementtype vectors are used, and the efficiency can be increased 2-3-fold simply by maximizing the electroporation condition for gene transfer. Similar enhancement could be obtained by inactivating DNA repair proteins, such as BLM or DNA ligase IV; however, perturbing the cellular DNA repair system might cause unexpected genomic instability involving off-target effects, this might also be the case for nuclease-boosted gene targeting. It is important to note that, when using exon-trapping-type vectors, the targeting efficiency can be elevated to more than $50 \%$ in the Nalm- 6 cell line, meaning that screening of several drug-resistant clones is sufficient to obtain the mutant of interest.

We also developed a simple and rapid system to construct any exon-trapping-type vectors within one week,

Yokohama City University, Japan

Biomed Central 2010 Adachi; licensee BioMed Central Ltd. without the need for ligation reactions or restriction mapping. Although such vectors might only be applicable to human genes with relatively high levels of expression in the cell, overall our technology will help accelerate the human gene-knockout project.

Published: 11 October 2010

doi:10.1186/gb-2010-11-S1-P1

Cite this article as: Adachi: High-efficiency gene targeting in a human pre-B cell line: towards the human gene knockout project. Genome Biology 2010 11(Suppl 1):P1.

Submit your next manuscript to BioMed Central and take full advantage of:

- Convenient online submission

- Thorough peer review

- No space constraints or color figure charges

- Immediate publication on acceptance

- Inclusion in PubMed, CAS, Scopus and Google Scholar

- Research which is freely available for redistribution

Submit your manuscript at www.biomedcentral.com/submit 